Bryant University

Bryant Digital Repository

8-22-2017

\title{
Student Perceptions and Learning Outcomes: Evidence from the Education Testing Service (ETS) Major Field Test in Business
}

\author{
David C. Ketcham \\ Bryant University, dketcham@bryant.edu \\ Peter J. Nigro \\ Bryant University, pnigro@bryant.edu \\ Michael Roberto \\ Bryant University, mroberto@bryant.edu
}

Follow this and additional works at: https://digitalcommons.bryant.edu/finjou

Part of the Business Commons, and the Education Commons

\section{Recommended Citation \\ Ketcham, David C.; Nigro, Peter J.; and Roberto, Michael, "Student Perceptions and Learning Outcomes: Evidence from the Education Testing Service (ETS) Major Field Test in Business" (2017). Finance Journal Articles. Paper 73. \\ https://digitalcommons.bryant.edu/finjou/73}

This Article is brought to you for free and open access by the Finance and Financial Services Faculty Publications and Research at Bryant Digital Repository. It has been accepted for inclusion in Finance Journal Articles by an authorized administrator of Bryant Digital Repository. For more information, please contact dcommons@bryant.edu. 


\title{
Student Perceptions and Learning Outcomes:
}

\section{Evidence from the Education Testing Service (ETS) Major Field Test in Business}

\author{
David Ketcham \\ Associate Professor of Finance \\ Bryant University, Smithfield, RI USA \\ Email: dketcham@bryant.edu \\ (401) 232-6456 \\ Peter Nigro \\ Sarkisian Chair and Professor of Finance \\ Bryant University, Smithfield, RI USA \\ Michael Roberto \\ Trustee Professor of Management \\ Bryant University, Smithfield, RI USA
}

August 22, 2017

The authors are grateful to Bob Jones and Laura Hayward for supplying the data used in the paper. We are solely responsible for any remaining errors. 


\title{
Student Perceptions and Learning Outcomes:
}

\section{Evidence from the Education Testing Service (ETS) Major Field Test in Business}

\begin{abstract}
:
We examine course evaluation data from the core finance course and analyze how these data relate to performance on the finance portion of the Educational Testing Service Major Field Test in Business (ETS). We find that gender, SAT scores, GPA and concentration all have significant impacts on student performance. We also find that student perceptions of teaching and of how much knowledge they gained do not relate to the finance ETS score. Finally, we find that students who feel challenged in their finance core course do significantly better on the finance portion of the exam. This result is robust to different data partitions.
\end{abstract}

Keywords: student perception, student learning, ETS major field test in business, student demographics

\section{INTRODUCTION}

In this paper we examine course and instructor evaluation data from the core finance course in our required curriculum and analyze how these data relate to performance on the finance portion of the Educational Testing Service Major Field Test in Business (ETS). Specifically, we evaluate how ETS exam performance relates to student perceptions regarding the intellectual challenge of the course, increase in subject matter knowledge by the end of the class, and overall instructor teaching ability. To our knowledge, this is one of the first papers to examine how course evaluation scores relate to standardized exam performance in a particular subject area at a university.

Numerous papers have examined the overall ETS results for insights into various questions such as student knowledge relative to other institutions [Marchandeni et al., 2001], the correlation between SAT scores and ETS exam results ([Marchandani, 2001], [Bean and Bernardi , 2002]. [Bycio and Allen, 2007], and[ Bielinski-Kwapisz,, 2012a, 2012b]) and the importance of GPA in explaining test scores ([Bycio and Allen, 2007], [Terry et al., 2008], and [Settlage and Settlage, 2011]). A separate stream of literature ([Ramsden, 1992], [Marton and 
Booth,1997] and [Prosser and Trigwell,1997, 1999]) has focused on how teacher effectiveness ratings impact learning outcomes and test performance. However, no papers have analyzed the relationship between teacher evaluations and ETS exam scores.

The paper extends the previous literature in several ways by focusing solely on the finance sub-score of the ETS exam. We have taken this approach for several reasons. First, we control for the typical variables employed in models of ETS determinants such as standardized tests, GPA, gender and concentration. By focusing solely on finance, however, we also can control for the core finance course grade where these concepts are taught. For non-finance majors we capture difference in exposure to finance by controlling for the number of finance courses, as well as the time since the course was taken. Most importantly, however, we incorporate information from the student perception forms in this introductory finance class to assess if the average student ratings on several key variables relate to their demonstrated finance knowledge as determined by their ETS finance sub-score. Specifically, the student forms allow us to incorporate variables gauging student perceptions of teaching ability, knowledge attainment, and intellectual challenge.

The remainder of the paper is structured as follows. Section 2 summarizes the previous literature on ETS determinants. Section 3 provides descriptive statistics on ETS scores, as well as other factors that might impact student achievement on the finance portion of the test such as gender, concentration, course grades, GPA and standardized test scores. Section 4 outlines three different testable hypotheses and provides the empirical results of our finance ETS models. We also examine the robustness of our results by examining several subsample and gender specific ETS determinant models. Section 5 provides implications, concluding remarks, and raises potential questions for future research. 


\section{LITERATURE REVIEW}

The Educational Testing Service Major Field Test in Business (ETS) is a 120 question, timed, multiple choice examination testing student knowledge in nine functional areas of business: accounting, economics, management, quantitative business analysis, finance, marketing, legal and social environment, information systems, and international issues. Questions can span more than one topic area, and are not equally weighted. Since 2013, more than 600 colleges and universities have administered the exam, and many use the results as part of their AACSB-required assurance of learning initiative. A variety of researchers have examined factors affecting student performance on the ETS exam. Allen and Bycio [1997], in a study of 65 accounting students and 368 non-accounting majors, found that test scores were significantly and positively related to SAT scores (both verbal and math) and GPA in business classes. They found performance differences across majors, but no differences in performance due to gender.

Bagamery, Lasik, and Nixon [2005] expand the set of variables and find that gender (women did more poorly on the ETS exam than did men), GPA in pre-admission courses, GPA in core courses and whether or not the student took the SATs were all significant contributors to exam performance. Bycio and Allen [2007] found no performance differences based on gender, but found that SAT-V, SAT-M, and GPA in business courses were all significant and positively related to ETS performance. They also construct a measure of motivation based on surveys taken immediately after a presentation on the importance of AACSB reaffirmation and the use of the test in that effort, and immediately before administering the exam. They found student motivation to be positively and significantly related to test performance. 
In a similar study, Settlage and Settlage [2011] found that major (accounting majors did better than business administration or marketing majors), business course GPA and ACT scores were significantly related to ETS scores. They also discovered that women significantly underperformed their male counterparts. Similar results were found by Chowdhury and Wheeling [2013] who examined separately the performance of four student cohorts between 2007 and 2010. They found that gender was a significant factor in explaining ETS scores, as were GPA and ACT scores, but that the magnitude of the coefficients varied substantially over time. For example, the gender coefficient varied from 4.48 to 9.32 points (the exam is scored on a 120 - 200 point basis). Bielinska-Kwapisz and Brown [2013] explore the gender differences in some detail. Among other things, they discovered that male student exam scores increased given extra credit incentives, but female scores did not.

Ritchie, Rodriguez, Harrison, and Wates [2014] examine the relation between ETS scores and prerequisite general education course grades (which did not include Financial Management) for 202 students at a Southeastern public liberal arts institution that evaluates student performance on six general education courses before offering admission to the School of Business. They find the only factors affecting performance are grades in second-semester English course (Composition and Literature), Microeconomics, and predicted GPA based on admissions criteria.

In one of the few studies to analyze ETS subsection scores, Settlage and Wollscheid [2015], using a relatively small sample of 129 students, find that many results of earlier studies hold at the subsection score levels. For example, females underperform males in all content areas except marketing, and do so significantly in the content areas of accounting, economics, quantitative analysis, finance, and information systems. GPA and ACT scores are significant and positive contributors to the scores in almost all content areas, and major field of study 
matters - marketing majors underperform management majors in all content areas, and significantly do so in five. It should be noted that most prior studies are constructed using relatively small samples, and generally the students are unique to one institution.

There is also a substantial body of literature on student perceptions of instructor quality and their relationship to learning outcomes. Centra [1977], in a study involving 44 instructors across 72 sections of seven college level introductory courses, found that ratings of teacher effectiveness and the value of the course to students were highly correlated with mean exam performance. Other researchers [Ramsden,1992], [Marton and Booth,1997] and [Prosser and Trigwell,1997, 1999] have documented the influence that student perceptions of teaching have on learning approaches and learning outcomes. Hoffmann and Oreopoulos [2006] find no relationship between student outcomes and faculty rank, status, and salary, but find that instructors with high perceived quality experience lower dropout rates. Similarly, Cheng [2015] found that tenure status had no effect on undergraduate evaluations of instructor quality. De Paola [2009], in a study of almost 800 students assigned to a first-level business and economics class in an Italian university, finds a positive relationship between learning (as measured by course grade) and teacher experience and research activity, but little evidence whether or not instructor attributes relate to further study in the field.

In a study of 839 medical students, Stehle, Spinath, and Kadmon [2011] find a strong positive relationship between student evaluations of teaching and scores on a practical exam, but no significant relationship between evaluations and performance on a multiple choice exam. Beleche, Fairris and Marks [2012], in a study of 1100 students at a public university, find a positive relationship between students' perceptions of course quality and learning outcomes as measured by pre-and post-course test scores, controlling for student demographics. Braga, Paccagnella, and Pellizzari [2014], using standardized course grades as a measure of teaching 
effectiveness, find a negative and significant relationship between student perceptions of teaching quality and course outcomes. They suggest that the "results challenge the validity of students' evaluations of professors as a measure of teaching quality.” (p. 82)

Finally, and perhaps most definitively, Uttl, White, and Gonzalez [2017], in a metaanalysis, find that much of the evidence suggesting a relationship between student evaluations of teaching and learning outcomes is an artifact of small sample sizes and/or publication bias. They assert that an analysis of studies of papers involving large-sample, multi-section courses reveals that no relationship exists between learning outcomes and perceived instructor quality.

\section{THE DATA}

This paper pulls together several unique data fields from a mid-sized regional university located in the northeast. The university is accredited by the New England Association of Schools and Colleges (NEASC) and AACSB International. The university is predominantly a business school; about $80 \%$ of its students achieve BS in Business Administration or BS in International Business degrees. All students are required to take a business core class in Financial Management, which can be taken as early as sophomore year.

The first source of data is compiled from the ETS Major Field Exam-Business which is administered as part of a capstone class in first or second semester of the students' senior year. The ETS exam score ranges from 120 to 200 and assesses student competency in nine distinct subject areas: Accounting, Economics, Finance, Information Systems, International Issues, Legal and Social Environment, Management, Marketing, and Quantitative Business Analysis. The ETS exam also reports sub-section scores ranging from 0-100 for each of these respective areas, allowing faculty and administrators to easily assess areas of possible deficiency in the

curriculum or in student comprehension. Questions can overlap several of the subject areas. For 
example, a finance question could influence not only the finance score but economics and accounting as well, depending on the nature of the question. To ensure that students give their best effort, the university provides a grade increase in the capstone business policy course for superior performance on the ETS exam. ${ }^{1}$

A second source of data is the student perception forms that University faculty are required to administer. The student perception surveys are administered on-line, and instructors are required to allot class time for their completion. Generally, the response rate is over $80 \%$. The university employs a survey instrument developed and validated by scholars at another university, and about which those scholars have conducted extensive research [Driscoll \& Cadden, 2010]; [ Simione, Cadden, \& Mattie, 2011]). The perception forms include open-ended questions on course design and content, the usefulness of the class, what students liked about the course and ways in which the course could be improved. In addition, the student forms have questions with responses on a five point scale $(5=$ excellent, $4=$ very good, $3=$ good, 2 =fair and $1=$ poor). We focus on three questions, which we deemed most important from the perception forms:

1. I have increased my overall knowledge of the subject matter (1 to 5)

2. I feel challenged intellectually by the course. (1 to 5)

3. Rate the instructor's teaching ability in this class (1 to 5)

Since the surveys are anonymous to protect student identities, we constructed class means for each of these questions. Professor level means were constructed over academic years (e.g., 2011-2012) and may include multiple sections taught during that time period. Thus, student perception of teaching responses were dynamic over the time period, since professors can address student concerns over time. 
A third source of student data was obtained from the university registrar. This information included information on student concentration, grades (final GPA and Financial Management course grade), standardized test results, as well as information on the number of finance classes taken and their timing. We merged these three data sets: ETS student scores, average student perception of professor performance, and student level information from the registrar.

Table 1 provides summary information on the total ETS scores and each of the subject sub-scores. The scores range from a low of 44 in the quantitative business questions to a high of 68 on the marketing sub-score. We focus on the ETS finance score, however, for two reasons. First, the finance sub-score represents the largest differential between males and females. Second, we only have student perceptions of finance professors. ${ }^{2}$

\section{Table 1 about here}

In examining student performance on the ETS finance score we use the following:

- FINSCORE: Reported score on the finance content area of the ETS exam, ranging from 6 to 100 .

- ATHLETE: An indicator variable taking on a value of 1 if the student participated in NCAA Intercollegiate athletics, and 0 otherwise.

- HONORS: An indicator variable taking on a value of 1 if the student participated in the University Honors program and 0 otherwise.

- FEMALE: An indicator variable taking on the value of 0 for males and 1 for females. ${ }^{3}$

- Concentration: A series of indicator variables allowing us to control for the student's field of study (concentration). Management is the default concentration. 
- SAT-V: Reported score on the verbal portion of the Scholastic Aptitude Test. ${ }^{4}$

- SAT-M: Reported score on the mathematics portion of the Scholastic Aptitude Test.

- GPA: The student's overall GPA at graduation, reported by the Office of the Registrar.

- FMGRADE: The student's grade in the university's introductory Financial Management course. $^{5}$

- NUMFIN: For non-finance majors, we report the number of finance classes taken. ${ }^{6}$

- TIME: The length of time (in months) between when the student completed the introductory Financial Management class and the ETS exam. This number is reported for non-finance concentrators only. ${ }^{7}$

- Cohort: A series of indicator variables that allow us to control for graduation cohort.

- TEACH: Average student perception of professor's teaching ability, based on academicyear averages across all sections taught by the instructor.

- LEARN: Average student perception of how much they learned in the course, based on academic-year averages across all sections taught by the instructor.

- CHALLENGE: Average student perception of how challenging they perceived the course to be, based on academic-year averages across all sections taught by the instructor. Table 1 provides descriptive statistics for the full sample of over 2,000 students that took for the ETS exam over the 2011-2016 time period. Panel B and C breaks this information down by gender; Panel D reports the significance of the differences between males and females. Table 1 shows that only 39.7 percent of the sample is female (809/2038). Although we focus on the finance sub-score, Table 1 provides information for all ETS subsections. Females do significantly worse on all sections of the exam except for the Management section. The greatest gender disparity in the section sub-scores, however, is the finance sections with males significantly outperforming females by over 8.5 points (54.34 vs 45.71$)$. 
Female students are significantly more likely be enrolled in the Honors program (13.0\% vs $10.6 \%)$ and have significantly higher GPAs (3.26 vs 3.16) than their male counterparts. Standardized test scores of the students tell a different story. The sample mean for the Math SAT is 584 , but males score significantly higher (591 vs. 576) than their female counterparts. There are no differences, however, in the groups' SAT verbal scores or in their introduction to finance grades.

Part of the finance ETS differential could be driven by the business concentration chosen by the male and female students. Male students are significantly more likely to choose to be a finance (29.7\% vs $10.0 \%)$ and CIS (2.62 vs $1.26 \%$ ) major, while females are more likely to earn degrees in management (15.7\% vs $12.0 \%)$, marketing (32.0\% vs. $15.5 \%)$ and international business (15.2\% vs. $10.5 \%)$.

When examining student perceptions of teaching, female students take classes that have professors with significantly higher teaching evaluations (3.73 vs 3.65), learning (4.05 vs 3.98) and challenge scores (4.32 vs 4.28). It should be noted that these evaluations are not student level but professor level averaged over the course of an academic year.

\section{EMPIRICAL RESULTS}

This section examines the determinants of student finance sub-scores on the ETS major field in business exam. We estimate a simple ordinary least squares model that controls for several factors including student demographics, concentration, standardized testing results and student performance. This paper, however, extends the previous literature by incorporating professor level information from the student perception forms. 
Previous empirical research has shown several factors to be important determinants of overall ETS scores. We follow a similar approach when examining the finance sub-score. The general specification of the model can be shown as:

FINSCORE $=\beta_{0}+\beta_{1}$ FEMALE $+\beta_{2}$ ATHLETE $+\beta_{3}$ HONORS $+\beta_{4}$ ACCOUNTING $+\beta_{5}$ FINANCE $+\beta_{6}$ MARKETING $+\beta_{7}$ INTERNATIONALBUS $+\beta_{8} \mathrm{CIS}+$ $\beta_{9}$ ENTREPRENEURSHIP $+\beta_{10}$ SAT-M $+\beta_{11}$ SAT-VL $+\beta_{12}$ GPA $+\beta_{13}$ FSGRADE $+\beta_{14}$ NUMFIN $+\beta_{15}$ TIME $+\beta_{16}$ TEACH $+\beta_{17}$ LEARN $+\beta_{18}$ CHALLENGE $+\beta_{19}$ GPA $*$ CHALLENGE + $\sum_{j=2012}^{2016} \beta_{i}$ COHORT $_{\mathrm{j}}+\varepsilon$

We report the results for several different model specifications of the finance sub-score determinant equation, incorporating different elements from the student perception forms as well as the typical covariates employed in the ETS literature. For example, we control for gender (FEMALE) and hypothesize that there should be no difference in the performance between men and women, controlling for all other variables. Second, we control for intercollegiate sport participation (ATHLETE). Our expectation is that athletes pay a penalty for their sport-related time commitments. Thus, we expect the coefficient on ATHLETE to be negative. Conversely, we expect HONORS students, ceteris paribus, to do better on the finance portion of the ETS exam. We also control for student concentration, via indicator variables for accounting, finance, CIS, marketing and international business. The omitted concentration is management. Given that we are focusing on the finance score we expect finance concentrators and other quantitative disciplines, such as accounting, to score higher than management and marketing concentrators.

Standardized test taking ability and overall student knowledge might impact the ETS finance score. Thus, we include both SAT verbal math scores (SAT-V and SAT-M) as proxies for standardized test-taking abilities, as well as the student's overall final GPA. We expect all three of these variables to be positively related to the ETS finance sub-score. We also include 
the grade earned in the introduction to finance course (FSGRADE) which is the core course which provides coverage for the material for the exam. For non-finance concentrators only, we also include the time in months (TIME) since the student took the course and the number of finance classes taken (NUMFIN) We expect the higher introduction to finance grade, the higher the finance ETS score, while the length of time since the course was taken to have a negative impact since student finance knowledge might erode over time. Finally, we include ETS cohort dummies since the difficulty of the finance portion of the exam may differ over the various years. ${ }^{8}$ The omitted year in the OLS regression is 2011.

Most importantly, we are the first paper to our knowledge to incorporate student perception forms into an analysis of the determinants of ETS scores. We pull three critical variables from the introduction to finance student perception forms. Specifically, we include measures of student perceptions of teaching ability (TEACH), how challenged students feel in the course (CHALLENGE) and how much knowledge the students believed they gained in the course (LEARN). Each question from the course evaluations has associated with it at least one hypothesis about the sign of the relationship between the student perception scores and ETS performance.

Question 1: I have increased my overall knowledge of the subject matter (1 to 5) (LEARN) Hypothesis 1: students that believe that they gained knowledge in the introduction to finance course will do better on the exam. The sign on LEARN will be unambiguously positive.

Question 2: I feel challenged intellectually by the course. (1 to 5) (CHALLENGE)

Hypothesis 2a: Students who feel challenged in the course will be more engaged, and will do better on the finance portion of the exam. The sign on CHALLENGE will be positive. 
Hypothesis 2b: Students who struggle with the finance course material and concepts may report that they felt intellectually challenged. Students who rate the course as challenging will do more poorly on the ETS exam than those who regard it as a lesser challenge. The sign on CHALLENGE will be negative.

Question 3: Rate the instructor's teaching ability in this class (1 to 5) (TEACH)

Hypothesis 3a: A priori, we expect students will learn more and do better on the ETS finance portion from finance teachers receiving high course evaluations. Thus, we expect a positive sign on TEACHING.

Hypothesis 3b: Students give high evaluation marks to teachers who require little work and provide high grades. The coefficient on TEACH will be negative.

Table 2 presents from the finance ETS determinant equation that incorporates variables from previous studies as well as the new information from the student perception forms. The table has four panels. Panel A includes a variable that measures the mean student perception of teaching ability (TEACHING); Panel B examines student perceptions of the knowledge gained in the course (KNOWLEDGE); Panel C assesses the impact of how student perceptions of intellectual challenge; Panel D., incorporate all three measures - teaching, learning and challenge in one regression; and Panel E incorporates the CHALLENGE variable and an interaction between CHALLENGE and GPA. 


\subsection{Student Demographics}

Table 2 confirms several results from the previous literature on ETS determinants. First, similar to overall ETS scores, female student score on average seven points lower than their male counterparts on the finance part of the ETS exam. This result is consistent across all panels. Second, student participants in NCAA athletics (ATHLETE) score no different than their counterparts. This suggests that even with the time commitment associated with athletics, these students appear to manage their time effectively and perform equally to peers in the finance portion of the exam. Finally, student who are in the Honors program (HONORS) score significantly higher than their counterparts. The student completing this program are among the smartest and most conscientious students at the university.

\subsection{Student Concentration}

As expected the student's chosen concentration significantly impacts the finance ETS score. Specifically, students concentrating in finance will score on average thirteen points higher relative to the omitted management group. This result is not surprising since these concentrators take a minimum of 6 courses in finance after the introductory course and are exposed to key finance concepts repeatedly during their tenure at the university. As expected, accounting students also score significantly higher, roughly 5.5 points higher in all the panels. Given the overlap between accounting and finance concepts, this result does not prove surprising. There are no other statistically significant differences in finance sub-score for any of the remaining concentrations.

\subsection{Standardized Test Scores /Grades}

Both SAT-Verbal and SAT-Math are significant and positive contributors to ETS finance sub-score performance. Students exhibiting the ability to succeed on standardized tests in the 
past tend to do better on the finance portion of the ETS exam. Student GPA also has a significant positive impact on the sub-score. Students earning higher grades do better on the exam. Third, since the finance material covered on the ETS exam is supposed to be included in the introductory finance course, we expect higher course grades to result in higher ETS sub-score. This positive relationship holds across almost all of the panels. Fourth, the number of finance courses taken may also impact the finance ETS score. We disentangle finance concentrators from this measure by setting this variable equal to zero, since they all take a minimum of six finance courses. Each additional finance course results in a significant increase in finance subscore of roughly two points. This result is robust across all model specifications. Finally, given that the knowledge of those students who are not consistently exposed to finance might decline over time, we include a variable that captures the time since the introductory course was taken. The variable has no impact on finance sub-score in any of the specifications.

\subsection{Student Cohort Effects}

All specifications control for cohort effects with the first year of the study (2011) being the omitted year. We control for cohort effects for two reasons. First, the level of difficulty of the exam may vary from year to year as exam questions change. Second, the quality of students taking the exam can also vary over the time period examined. We find that several cohort years score significantly lower than the omitted year in all of the panels. For example, Panel A shows that the 2013 graduating cohort scored 3.6 points lower when compared to the 2011 cohort.

\subsection{Student Perception Form Responses}

The major contribution of the paper is the incorporation of student perception forms as an explanatory variable with regard to ETS exam performance. First, and surprisingly, the overall teacher rating $(\mathrm{TEACH})$ in the introductory finance is unrelated to the ETS finance score. 
In other words, the average student perception of a professor's teaching ability has no impact on the finance sub-score. Second, we find that the average student perception of how much knowledge they gained through taking the introductory finance course (LEARN) also has no relationship to the finance sub-score. Most importantly, however, when we include a variable capturing the average level of how challenged the student feels in the course, it has a significant impact on the finance ETS score. For example, Panel C shows that for each 1 point increase in the challenge scale, the finance ETS score increases by 3.4 points. Panel D provides parameter estimates when we include all three student perception forms in the model, and the CHALLENGE variable result holds. In fact, CHALLENGE is the only variable from the perception forms to be significantly related to the finance sub-section score when analyzed individually or as a group. As a final check, we interact the CHALLENGE variable with GPA. We find that as GPA increases the CHALLENGE effect becomes less important. For the average GPA of 3.16, the impact on the ETS finance sub-score is 3.6 points $\left(3.16^{*}(-4.48)+17.75\right)$. Alternatively, for a student one standard deviation below the mean (2.77) the impact of each one point increase in the CHALLENGE variable is 5.3 points. $(2.77 *(-4.48)+17.75)$. For a student with a perfect 4.0 GPA, however, the impact disappears.

\subsection{Robustness Checks}

The impact on finance score may be affected by the choice of concentration especially for finance and accounting concentrators. Second, the finance result score may also differ for students taking more than one finance course. Table 3 provides some robustness checks for our "CHALLENGE" result. Panel A omits finance concentrators from the sample. The CHALLENGE variable remains positive and significant. Panel B omits both finance and accounting concentrators from the regression, and we get identical results. Finally, to remove any potential bias from additional finance courses, Panel $\mathrm{C}$ shows estimates from the model for 
students that have taken only one finance course. The CHALLENGE variable remains significant at the 90 percent level. $^{9}$

\section{Table 3 about here}

Given the significant differences between males and females on their ETS finance scores, Table 4 provides another robustness check by estimating the model for males and females separately. Results are similar to previous tables. Most importantly, however, the CHALLENGE variable is similar in magnitude and statistically significant for both genders.

\section{Table 4 about here}

\section{CONCLUSIONS}

This study supports earlier studies examining student performance on the business ETS exam. Focusing only the finance portion of the exam, we find very similar results; gender, SAT scores, GPA and business concentration all have significant impacts on student performance. The important contribution of this paper, however, is the assessment of the relationship between student perception form information and ETS results. Using the average professor ratings from the introductory finance course allows us to examine several interesting hypotheses. First, do student perceptions of teaching ability correlate with standardized test scores in a key subject area? Second, does student perception of the knowledge they gained from the course exhibit a relationship with ETS exam performance? Finally, do students that feel more intellectually challenged in the core finance course do better on the finance portion of the ETS exam?

We find several new and important results. First, the overall student perception of teaching ability has no impact on the finance ETS score. Second, student perceptions of how 
much knowledge they gained in the course do not impact the finance ETS score when controlling for other factors. Finally, we find that students who feel challenged by their introductory finance course instructor do significantly better on the finance portion of the exam. This result is very robust to different subsamples, as well as for gender specific models. This results has important implications for both student learning, as well as faculty assessment.

Interestingly, we find a statistically significant interaction between intellectual challenge and GPA. Put simply, the level of intellectual challenge has a more substantial positive impact on ETS exam performance for the students with lower GPAs. The impact of challenge declines as overall student grades improve. What explains this finding? Perhaps the high performing students will do well on the finance section of the ETS exam regardless of their specific experience with an instructor in their introductory finance class. They are exceptional students who can master the finance material regardless of their experience with particular instructors. However, for the weaker students, having an intellectually challenging experience can be very meaningful and important, helping them to master the finance material and excel on the standardized exam.

The paper, however, suffers from several limitations. First, the results are only from one AACSB-accredited university in the northeast that primarily graduates student with business degrees. Thus, the results may not be generalizable to other schools with different missions, accreditation status or underlying student attributes. Second, given the anonymity of student perception forms, we were forced to employ class averages. In a perfect world, it would be better to examine student specific measures of perceived teaching ability, knowledge gained and course challenge. 
Future research should attempt to see if these results are generalizable across different disciplines or if the finance results are outliers. Second, the gender puzzle of why females have higher GPAs yet lower ETS scores holds for finance scores. Is there bias in the ETS test or differences in knowledge retention by gender? Finally, given the limited amount of research tying student perceptions to actual learning, more work needs to be done to examine this important link in more detail. 


\section{ENDNOTES}

${ }^{1}$ Students receive a half-letter grade increase in their course grade in BUS400 (Strategic Management capstone course required for seniors) if they score in the top $20 \%$ nationally on the ETS exam. They receive a half-letter grade decrease in their course grade if they score in the bottom $10 \%$ nationally on the ETS exam.

${ }^{2}$ One of the authors is the chair of the finance department at the university in this study. Therefore, this faculty member has access to the course evaluation data for finance professors only.

${ }^{3}$ During the 2010 to 2016, no students were classified as transgendered.

${ }^{4}$ In the case of multiple test taking, the Office of Admission uses the highest score. We follow a similar path. For both SAT-Verbal and SAT-Math.

${ }^{5}$ Students may take classes multiple times, either because of failure or to replace a lower grade. We use the recorded grade from the last time the student took the class.

${ }^{6}$ We exclude finance concentrators since they are continually exposed to finance concepts throughout their degree program.

${ }^{7}$ The exclusion of finance concentrators (who typically take 6 or more finance classes and are likely taking one or more concurrently with the ETS exam) lowers the averages reported in Table 1. In the regression models, the coefficients will relate to non-finance majors only; the TIME and NUMFIN effects for finance concentrators will be embedded in the coefficient on the finance indicator variable.

${ }^{8}$ The cohort years 2012 and 2016 score significantly higher (52.5 vs 50.0) when compared to the omitted years in a simple t-test.

${ }^{9}$ We have omitted the GPA*Challenge variable from Tables 3 and 4 . In all cases the coefficients were insignificant. 


\section{REFERENCES}

Allen, J., and P. Bycio (1997). "An Evaluation of the Educational Testing Service Major Field Achievement Test in Business," Journal of Accounting Education, 15 (4), 503-514.

Bagamery, B., J. Lasik, and D. Nixon (2005). "Determinants of Success in the ETS Major Field Exam for Business in an Undergraduate Multisite Regional University Business Program, ” Journal of Education for Business 81 (1), 55-63.

Bean, D. R. and Bernardi, R. A. (2002). Performance on the Major Field Test in Business: The explanatory power of SAT scores and gender. Journal of Private Enterprise, 17(2), 172-178.

Beleche, T., D. Fairris, and M. Marks (2012). "Do Course Evaluations Truly Reflect Student Learning? Evidence from an Objectively Graded Post-test," Economics of Education Review, 31 (5), 709719.

Bielinska-Kwapisz, A., Brown, F. W., and Semenik, R. (2012a). Interpreting standardized assessment test scores and setting performance goals in the context of student characteristics: The case of the Major Field Test in Business. Journal of Education for Business, 87(1), 7-13.

Bielinska-Kwapisz, A., Brown, F. W., and Semenik, R. (2012b). Is higher better? Determinants and comparisons of performance on the Major Field Test in Business. Journal of Education for Business, 87(3), 159-169.

Bielinska-Kwapisz, A., and F. W. Brown (2013). "Differential Gender Performance on the Major Field Test-Business," Journal of Education for Business 88 (3), 159-166.

Braga, M., M. Paccagnella, and M. Pellizzari (2014), "Evaluating Students' Evaluations of Professors," Economics of Education Review, 41 (August), 71-88.

Bycio, P. and J. Allen (2007). "Factors Associated with Performance on the Educational Testing Service (ETS) Major Field Achievement Test in Business (MFAT-B)," Journal of Education for Business, 82 (4), 196-201.

Centra, J. (1977). "Student Ratings of Instruction and Their Relationship to Student Learning," American Educational Research Journal, 14 (1), 17-24.

Cheng, D. (2015). "Effects of Professorial Tenure on Undergraduate Ratings of Teaching Performance," Education Economics, 23 (3), 338-357.

Chowdhury, M., and B. Wheeling (2013). "Determinants of Major Field Test (MFT) Score for Graduating Seniors of a Business School in a Small Mid-western University," Academy of Educational Leadership Journal, 17 (1), 59-71.

De Paola, M. (2009) "Does Teacher Quality Affect Student Performance? Evidence from an Italian University," Bulletin of Economic Research, 61 (4), 353-377.

Driscoll, J., and D. Cadden (2010). "Student Evaluation Instruments: The Interactive Impact Of Course Requirement, Student Level, Department And Anticipated Grade," American Journal of Business Education, 3 (5), 21-30.

Hoffmann, F., and P. Oreopoulos (2006). "Professor Qualities and Student Achievement, National Bureau of Economic Research Working Paper 12596, 
Marton, F., and S. Booth (1997), Learning and Awareness (Lawrence Erlbaum Associates, Rahwah, NJ).

Mirchandani D., Lynch, R., \& Hamilton, D.(2001). Using the ETS Major Field Test in Business: Implications for assessment. Journal of Education for Business, 77 (1), 51-56.

Prosser, M., and K. Trigwell (1997), "Using Phenomenography in the Design of Programs for Teachers in Higher Education,” Higher Education Research and Development, 16 (1), 41-54.

Prosser, M., and K. Trigwell (1999), Understanding Learning and Teaching: The Experience of Higher Education, (Society for Research into Higher Education and Open University press, Buckingham, UK).

Ramsden, P. (1992), Learning to Teach in Higher Education, (Routledge, London).

Ritchie, C., L. Rodriguez, D. Harrison, and K. Wates (2014). "The Impact of Prerequisite General Education Courses on the ETS Major Field Test for Business (MFT_B)," Journal of Education for Business, 89 (6), 292-299.

Settlage, D., and L. Settlage (2011). "A Statistical Framework for Assessmenr Using the ETS Major Field Test in Business," Journal of Education for Business, 86 (5), 274-278.

Settlage, D., and J. Wollscheid (2015). "Analyzing Student performance in Specific Area Indicators on the ETS Major Field Test in Business," Journal of Education for Business, 90 (6), 322-327.

Simione, K., D. Cadden, and A. Mattie (2011). "Standard of measurement for student evaluation instruments," Journal of College Teaching \& Learning, 5 (12), 45-58.

Stehle, S., B. Spinath, and M. Kudmon (2012). "Measuring Teaching Effectiveness: Correspondence Between Students' Evaluations of Teaching and Different Measures of Student Learning," Research in Higher Education, 51 (1), 888-904.

Terry, N., Mills, L., and Sollosy, M. (2008). Student grade motivation as a determinant of performance on the business Major Field ETS exam. Journal of College Teaching \& Learning, 5(7), 27-32.

Uttl, B., C. White, and D. Wong Gonzalez (2017). "Meta-Analysis of Faculty's Teaching Effectiveness: Student Evaluation of Teaching Ratings and Student Learning Are Not Related," Studies in Educational Evaluation, (September), 22-42. 


\begin{tabular}{|c|c|c|c|c|c|c|c|c|}
\hline & & able $1 \mathrm{D}$ & riptive Sta & tistics & & & & \\
\hline & $\begin{array}{r}\text { Pan } \\
\text { Full S } \\
\mathrm{n}=2 \\
\end{array}$ & $\begin{array}{l}\text { l A } \\
\text { mple } \\
38 \\
\end{array}$ & 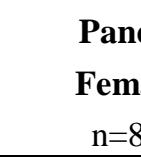 & & $\begin{array}{r}\text { Pan } \\
\text { Panel C } \\
\mathrm{n}=1 \\
\end{array}$ & $\begin{array}{l}\text { C. } \\
\text { Males } \\
29 \\
\end{array}$ & $\begin{array}{r}\text { Panel D } \\
\text { Differen } \\
\text { Females- M } \\
\end{array}$ & \\
\hline Variable & Mean & $\begin{array}{l}\text { Std } \\
\text { Dev }\end{array}$ & Mean & $\begin{array}{l}\text { Std } \\
\text { Dev }\end{array}$ & Mean & $\begin{array}{c}\text { Std } \\
\text { Dev }\end{array}$ & Differnc & \\
\hline ETS Scores & & & & & & & & \\
\hline Total Score & 160.169 & 10.832 & 157.203 & 9.955 & 162.122 & 10.947 & -4.919 & * \\
\hline Finance Score (FINSCORE) & 50.917 & 16.369 & 45.716 & 14.094 & 54.340 & 16.858 & -8.624 & * \\
\hline Management Score & 64.178 & 11.743 & 64.147 & 11.845 & 64.199 & 11.680 & -0.051 & \\
\hline Accounting Score & 50.480 & 15.736 & 47.902 & 15.167 & 52.177 & 15.879 & -4.274 & * \\
\hline Economics Score & 47.808 & 15.334 & 43.467 & 13.988 & 50.665 & 15.516 & -7.198 & * \\
\hline Quantitative Bus. Score & 44.201 & 14.953 & 41.794 & 14.283 & 45.785 & 15.176 & -3.992 & * \\
\hline Marketing Score & 68.562 & 13.487 & 67.428 & 13.821 & 69.308 & 13.216 & -1.881 & * \\
\hline Information Systems Score & 57.979 & 14.933 & 56.713 & 14.498 & 58.812 & 15.160 & -2.099 & * \\
\hline Legal, Social Environment Score & 63.806 & 14.781 & 61.381 & 14.516 & 65.402 & 14.743 & -4.021 & * \\
\hline International Issues Score & 52.730 & 17.450 & 50.839 & 16.810 & 53.979 & 17.756 & -3.140 & * \\
\hline Demographics & & & & & & & & \\
\hline ATHLETE & 0.153 & 0.360 & 0.150 & 0.357 & 0.155 & 0.362 & -0.005 & \\
\hline HONORS & 0.106 & 0.308 & 0.130 & 0.336 & 0.090 & 0.287 & 0.039 & * \\
\hline Concentration & & & & & & & & \\
\hline ACCOUNTING & 0.250 & 0.433 & 0.244 & 0.429 & 0.254 & 0.435 & -0.010 & \\
\hline FINANCE & 0.219 & 0.414 & 0.100 & 0.300 & 0.297 & 0.457 & -0.197 & * \\
\hline MARKETING & 0.221 & 0.415 & 0.320 & 0.467 & 0.155 & 0.362 & 0.165 & * \\
\hline INTERNATIONAL BUSINESS & 0.124 & 0.329 & 0.152 & 0.359 & 0.105 & 0.307 & 0.047 & * \\
\hline CIS & 0.024 & 0.153 & 0.011 & 0.105 & 0.033 & 0.178 & -0.021 & * \\
\hline ENTREPRENEURSHIP & 0.028 & 0.165 & 0.016 & 0.126 & 0.036 & 0.186 & -0.020 & * \\
\hline MANAGEMENT & 0.135 & 0.342 & 0.157 & 0.364 & 0.120 & 0.326 & 0.037 & * \\
\hline Standardized Test Scores /Grades & & & & & & & & \\
\hline SAT-M & 585.954 & 62.027 & 576.836 & 61.087 & 591.957 & 61.933 & -15.121 & $*$ \\
\hline SAT-V & 546.894 & 62.329 & 547.522 & 62.941 & 546.481 & 61.945 & 1.041 & \\
\hline GPA & 3.164 & 0.391 & 3.259 & 0.364 & 3.101 & 0.396 & 0.158 & $*$ \\
\hline FMGRADE & 2.965 & 0.788 & 3.000 & 0.786 & 2.943 & 0.788 & 0.057 & \\
\hline NUMFIN & 1.348 & 1.572 & 1.410 & 1.399 & 1.308 & 1.676 & 0.103 & \\
\hline TIME & 10.800 & 8.689 & 12.231 & 7.986 & 9.858 & 9.002 & 2.373 & $*$ \\
\hline
\end{tabular}

* indicates significance at the $5 \%$ level 


\begin{tabular}{|c|c|c|c|c|c|c|c|c|}
\hline & Table 1 & escript & tatistics & ontinue & & & & \\
\hline & $\begin{array}{r}\text { Pan } \\
\text { Full S } \\
n=2\end{array}$ & $\begin{array}{l}\text { A } \\
\text { nple } \\
38\end{array}$ & $\begin{array}{r}\text { Pan } \\
\text { Fem } \\
n=\varnothing\end{array}$ & & $\begin{array}{r}\text { Pan } \\
\text { Panel c } \\
n=1\end{array}$ & $\begin{array}{l}\text { C. } \\
\text { Males } \\
29\end{array}$ & $\begin{array}{r}\text { Panel I } \\
\text { Differen } \\
\text { Females- N }\end{array}$ & $\begin{array}{l}\text { o. } \\
\text { ice } \\
\text { Iales }\end{array}$ \\
\hline Variable & Mean & $\begin{array}{l}\text { Std } \\
\text { Dev }\end{array}$ & Mean & $\begin{array}{l}\text { Std } \\
\text { Dev }\end{array}$ & Mean & $\begin{array}{l}\text { Std } \\
\text { Dev }\end{array}$ & Differn & \\
\hline ETS Cohorts & & & & & & & & \\
\hline 2011 & 0.051 & 0.220 & & & & & & \\
\hline 2012 & 0.165 & 0.372 & 0.174 & 0.380 & 0.159 & 0.366 & 0.015 & \\
\hline 2013 & 0.195 & 0.396 & 0.201 & 0.401 & 0.190 & 0.393 & 0.011 & \\
\hline 2014 & 0.222 & 0.416 & 0.222 & 0.416 & 0.221 & 0.415 & 0.001 & \\
\hline 2015 & 0.193 & 0.395 & 0.172 & 0.377 & 0.207 & 0.405 & -0.035 & \\
\hline 2016 & 0.174 & 0.379 & 0.169 & 0.375 & 0.177 & 0.382 & -0.008 & \\
\hline Student Teaching Perceptions ( & & & & & & & & \\
\hline TEACH & 3.694 & 0.817 & 3.753 & 0.789 & 3.655 & 0.833 & 0.098 & * \\
\hline LEARN & 4.014 & 0.474 & 4.055 & 0.461 & 3.986 & 0.481 & 0.069 & * \\
\hline CHALLENGE & 4.299 & 0.364 & 4.323 & 0.347 & 4.284 & 0.374 & 0.039 & * \\
\hline GPA*CHALLENGE & 13.605 & 2.080 & 14.092 & 1.983 & 13.284 & 2.080 & 0.808 & $*$ \\
\hline
\end{tabular}

* indicates significance at the $5 \%$ level 
Table 2 Regression Results

\begin{tabular}{|c|c|c|c|c|c|c|c|c|c|c|c|c|c|c|c|}
\hline & \multicolumn{3}{|c|}{ Panel A. Teaching } & \multicolumn{3}{|c|}{ Panel B. Knowledge } & \multicolumn{3}{|c|}{ Panel C. Challenge } & \multicolumn{3}{|c|}{$\begin{array}{l}\text { Panel D. Teaching, } \\
\text { Knowledge and } \\
\text { Challenge }\end{array}$} & \multicolumn{3}{|c|}{$\begin{array}{l}\text { Panel E. GPA-Challenge } \\
\text { Interaction }\end{array}$} \\
\hline & Parm & t-stat & & Parm & t-stat & & Parm & t-stat & & Parm & t-stat & & Parm & t-stat & \\
\hline Intercept & -18.550 & -3.910 & $* * *$ & -20.199 & -3.740 & $* * *$ & -33.036 & -5.780 & $* * *$ & -31.055 & -5.070 & $* * *$ & -94.635 & -3.160 & $* * *$ \\
\hline FEMALE & -7.522 & -11.300 & $* * *$ & -7.533 & -11.320 & $* * *$ & -7.581 & -11.440 & $* * *$ & -7.564 & -11.400 & $* * *$ & -7.595 & -11.460 & $* * *$ \\
\hline ATHLETE & -0.494 & -0.580 & & -0.472 & -0.560 & & -0.310 & -0.370 & & -0.338 & -0.400 & & -0.242 & -0.290 & \\
\hline HONOR & 2.054 & 1.870 & $*$ & 2.010 & 1.830 & $*$ & 2.152 & 1.970 & $* *$ & 2.273 & 2.070 & $* *$ & 2.136 & 1.960 & $* *$ \\
\hline \multicolumn{16}{|l|}{ Concentration } \\
\hline ACCOUNTING & 5.667 & 5.390 & $* * *$ & 5.697 & 5.420 & $* * *$ & 5.639 & 5.390 & $* * *$ & 5.564 & 5.310 & $* * *$ & 5.580 & 5.340 & $* * *$ \\
\hline FINANCE & 13.593 & 10.740 & $* * *$ & 13.676 & 10.850 & $* * *$ & 13.718 & 10.990 & $* * *$ & 13.530 & 10.730 & $* * *$ & 13.634 & 10.930 & $* * *$ \\
\hline MARKETING & 1.343 & 1.300 & & 1.344 & 1.300 & & 1.323 & 1.290 & & 1.318 & 1.280 & & 1.340 & 1.310 & \\
\hline INTERNATIONAL BUS. & 1.802 & 1.290 & & 1.696 & 1.200 & & 0.892 & 0.630 & & 1.009 & 0.700 & & 1.001 & 0.710 & \\
\hline CIS & 1.765 & 0.840 & & 1.740 & 0.830 & & 1.424 & 0.680 & & 1.439 & 0.690 & & 1.371 & 0.660 & \\
\hline ENTREPRENEURSHIP & 0.971 & 0.490 & & 0.979 & 0.500 & & 0.877 & 0.450 & & 0.843 & 0.430 & & 1.010 & 0.520 & \\
\hline \multicolumn{16}{|l|}{ Standardized Test Scores /Grades } \\
\hline SAT-M & 0.033 & 5.990 & $* * *$ & 0.033 & 6.000 & $* * *$ & 0.033 & 5.900 & $* * *$ & 0.032 & 5.820 & $* * *$ & 0.032 & 5.840 & $* * *$ \\
\hline SAT-V & 0.028 & 5.110 & $* * *$ & 0.028 & 5.110 & $* * *$ & 0.028 & 5.100 & $* * *$ & 0.028 & 5.090 & $* * *$ & 0.028 & 5.140 & $* * *$ \\
\hline GPA & 9.212 & 8.180 & $* * *$ & 9.242 & 8.210 & $* * *$ & 8.859 & 7.880 & $* * *$ & 8.740 & 7.750 & $* * *$ & 28.151 & 3.040 & $* * *$ \\
\hline FMGRADE & 1.040 & 1.950 & $*$ & 0.989 & 1.860 & $*$ & 1.305 & 2.480 & $* * *$ & 1.463 & 2.690 & $* * *$ & 1.334 & 2.530 & $* * *$ \\
\hline NUMFIN & 2.208 & 8.180 & $* * *$ & 2.206 & 8.180 & $* * *$ & 2.178 & 8.100 & $* * *$ & 2.178 & 8.090 & $* * *$ & 2.183 & 8.130 & $* * *$ \\
\hline TIME & -0.019 & -0.370 & & -0.014 & -0.280 & & -0.001 & -0.020 & & -0.011 & -0.210 & & -0.004 & -0.090 & \\
\hline \multicolumn{16}{|l|}{ ETS Cohorts } \\
\hline 2012 & -1.180 & -0.770 & & -1.135 & -0.740 & & -1.154 & -0.760 & & -1.256 & -0.820 & & -1.050 & -0.690 & \\
\hline 2013 & -3.673 & -2.430 & $* * *$ & -3.620 & -2.390 & $* * *$ & -3.626 & -2.410 & $* * *$ & -3.741 & -2.470 & $* * *$ & -3.565 & -2.370 & $* * *$ \\
\hline 2014 & -2.895 & -1.930 & $*$ & -2.781 & -1.840 & $*$ & -2.532 & -1.700 & $*$ & -2.754 & -1.830 & $*$ & -2.521 & -1.690 & $*$ \\
\hline 2015 & -3.633 & -2.360 & $* * *$ & -3.478 & -2.240 & $* * *$ & -2.930 & -1.920 & $*$ & -3.208 & -2.070 & $* *$ & -2.962 & -1.940 & $*$ \\
\hline 2016 & -1.553 & -1.020 & & -1.497 & -0.990 & & -1.174 & -0.780 & & -1.257 & -0.830 & & -1.061 & -0.700 & \\
\hline \multicolumn{16}{|l|}{ Student Perceptions } \\
\hline TEACH & -0.018 & -0.050 & & & & & & & & -0.084 & -0.100 & & & & \\
\hline LEARN & & & & 0.356 & 0.500 & & & & & -0.789 & -0.520 & & & & \\
\hline CHALLENGE & & & & & & & 3.453 & 3.940 & & 3.900 & 3.970 & $* * *$ & 17.758 & 2.580 & $* * *$ \\
\hline GPA*CHALLENGE & & & & & & & & & & & & & -4.480 & -2.100 & $* *$ \\
\hline R-Square & & & & 0.338 & & & 0.343 & & & 0.343 & & & 0.344 & & \\
\hline Adj R-Sq & & & & 0.331 & & & 0.336 & & & 0.336 & & & 0.337 & & \\
\hline
\end{tabular}

*** indicates significance at the $1 \%$ level

** indicates significance at the $5 \%$ level

* indicates significance at the $1 \%$ level 


\begin{tabular}{|c|c|c|c|c|c|c|c|c|c|}
\hline \multicolumn{10}{|c|}{ Table 3 Challenge Robustness Checks } \\
\hline & \multicolumn{3}{|c|}{ Panel A. } & \multicolumn{3}{|c|}{ Panel B. } & \multicolumn{3}{|c|}{ Panel C. } \\
\hline & \multicolumn{3}{|c|}{$\begin{array}{l}\text { Omit Finance } \\
\text { Concentrators }\end{array}$} & \multicolumn{3}{|c|}{$\begin{array}{l}\text { Omit Fnance and } \\
\text { Accounting } \\
\text { Concentrators }\end{array}$} & \multicolumn{3}{|c|}{$\begin{array}{l}\text { Students taking only one } \\
\text { finance course }\end{array}$} \\
\hline & Parm & t-stat & & Parm & t-stat & & Parm & t-stat & \\
\hline Intercept & -24.439 & -3.88 & $* * *$ & -14.472 & -1.89 & $*$ & -13.912 & -2.00 & $* *$ \\
\hline FEMALE & -6.082 & -8.62 & $* * *$ & -4.969 & -5.82 & $* * *$ & -5.596 & -6.93 & $* * *$ \\
\hline ATHLETE & -1.087 & -1.16 & & -1.087 & -1.02 & & -1.103 & -1.07 & \\
\hline HONORS & 1.924 & 1.61 & & 2.064 & 1.34 & & 1.608 & 1.16 & \\
\hline \multicolumn{10}{|l|}{ Concentration } \\
\hline ACCOUNTING & 6.060 & 5.89 & $* * *$ & & & & 6.471 & 5.93 & $* * *$ \\
\hline MARKETING & 1.173 & 1.17 & & 0.967 & 0.98 & & 0.951 & 0.91 & \\
\hline INTERNATIONAL BUS. & 1.211 & 0.87 & & -0.213 & -0.15 & & 14.001 & 1.08 & \\
\hline CIS & 1.422 & 0.70 & & 1.823 & 0.90 & & 1.327 & 0.63 & \\
\hline ENTREPRENEURSHIP & 0.766 & 0.40 & & 0.632 & 0.33 & & -0.190 & -0.09 & \\
\hline \multicolumn{10}{|l|}{ Standardized Test Scores /Grades } \\
\hline SAT-M & 0.035 & 5.65 & $* * *$ & 0.023 & 3.14 & $* * *$ & 0.034 & 4.71 & $* * *$ \\
\hline SAT-V & 0.026 & 4.30 & $* * *$ & 0.028 & 3.94 & $* * *$ & 0.025 & 3.49 & $* * *$ \\
\hline GPA & 6.719 & 5.38 & $* * *$ & 4.965 & 3.30 & $* * *$ & 6.347 & 4.43 & $* * *$ \\
\hline FMGRADE & 1.057 & 1.82 & $*$ & 1.029 & 1.51 & & 0.315 & 0.48 & \\
\hline NUMFIN & 2.290 & 8.69 & $* * *$ & 2.960 & 9.37 & $* * *$ & & & \\
\hline TIME & 0.011 & 0.22 & & 0.009 & 0.14 & & 0.027 & 0.52 & \\
\hline \multicolumn{10}{|l|}{ ETS Cohorts } \\
\hline 2012 & -0.395 & -0.25 & & -0.040 & -0.02 & & -0.038 & -0.02 & \\
\hline 2013 & -3.010 & -1.95 & $* *$ & -3.824 & -2.22 & $* * *$ & -3.046 & -1.62 & \\
\hline 2014 & -2.154 & -1.41 & & -2.405 & -1.43 & & -1.721 & -0.93 & \\
\hline 2015 & -2.717 & -1.72 & $*$ & -2.828 & -1.57 & & -2.654 & -1.41 & \\
\hline 2016 & -2.188 & -1.41 & & -1.214 & -0.71 & & -2.438 & -1.26 & \\
\hline \multicolumn{10}{|l|}{ Student Perceptions } \\
\hline CHALLENGE & 2.860 & 2.90 & $* * *$ & 2.849 & 2.21 & $* *$ & 1.798 & 1.69 & * \\
\hline $\mathrm{N}$ & 1592 & & & 1083 & & & 1203 & & \\
\hline R-Square & 0.301 & & & 0.295 & & & 0.234 & & \\
\hline Adj R-Sq & 0.291 & & & 0.282 & & & 0.222 & & \\
\hline
\end{tabular}

$* * *$ indicates significance at the $1 \%$ level

** indicates significance at the 5\% level

* indicates significance at the $10 \%$ level 


\begin{tabular}{|c|c|c|c|c|c|c|}
\hline \multicolumn{7}{|c|}{ Table 4 Robustness Check: Gender Specific Results } \\
\hline & \multicolumn{3}{|c|}{ Panel A. Females } & \multicolumn{3}{|c|}{ Panel B. Males } \\
\hline & Parm & t-stat & & Parm & t-stat & \\
\hline Intercept & -27.827 & -3.27 & $* * *$ & -40.894 & -5.34 & $* * *$ \\
\hline ATHLETE & -0.779 & -0.63 & & -0.276 & -0.24 & \\
\hline HONORS & 2.590 & 1.68 & $*$ & 2.357 & 1.54 & \\
\hline \multicolumn{7}{|l|}{ Concentration } \\
\hline ACCOUNTING & 6.503 & 4.45 & $* * *$ & 4.979 & 3.41 & $* * *$ \\
\hline FINANCE & 9.914 & 4.94 & $* * *$ & 14.171 & 8.59 & $* * *$ \\
\hline MARKETING & 3.228 & 2.41 & $* *$ & -1.001 & -0.65 & \\
\hline INTERNATIONAL BUS. & 1.740 & 0.90 & & 0.286 & 0.14 & \\
\hline CIS & 0.567 & 0.13 & & 1.479 & 0.59 & \\
\hline ENTREPRENEURSHIP & 4.232 & 1.17 & & -0.066 & -0.03 & \\
\hline \multicolumn{7}{|l|}{ Standardized Test Scores /Grades } \\
\hline SAT-M & 0.033 & 3.85 & $* * *$ & 0.032 & 4.41 & $* * *$ \\
\hline SAT-V & 0.028 & 3.29 & $* * *$ & 0.030 & 4.15 & $* * *$ \\
\hline GPA & 4.683 & 2.68 & $* * *$ & 10.826 & 7.36 & $* * *$ \\
\hline FMGRADE & 1.570 & 2.05 & $* *$ & 1.081 & 1.51 & \\
\hline NUMFIN & 2.202 & 5.10 & $* * *$ & 2.153 & 6.22 & $* * *$ \\
\hline TIME & 0.021 & 0.30 & & -0.004 & -0.06 & \\
\hline \multicolumn{7}{|l|}{ ETS Cohorts } \\
\hline 2012 & -1.160 & -0.56 & & -0.543 & -0.25 & \\
\hline 2013 & -4.310 & -2.11 & $* *$ & -2.415 & -1.12 & \\
\hline 2014 & -3.313 & -1.64 & & -1.443 & -0.68 & \\
\hline 2015 & -4.521 & -2.13 & $* *$ & -1.051 & -0.49 & \\
\hline 2016 & -4.207 & -2.03 & $* *$ & 1.281 & 0.60 & \\
\hline \multicolumn{7}{|l|}{ Student Perceptions } \\
\hline CHALLENGE & 3.499 & 2.54 & $* *$ & 3.630 & 3.19 & $* * *$ \\
\hline $\mathrm{N}$ & 809 & & & 1229 & & \\
\hline R-Square & 0.265 & & & 0.331 & & \\
\hline Adj R-Sq & 0.245 & & & 0.320 & & \\
\hline
\end{tabular}

*** indicates significance at the $1 \%$ level ** indicates significance at the 5\% level $*$ indicates significance at the $10 \%$ level 


\begin{tabular}{|c|c|c|c|c|c|c|}
\hline \multicolumn{7}{|c|}{ Table 4 Robustness Check: Gender Specific Results } \\
\hline \multirow[b]{3}{*}{ Intercept } & \multicolumn{3}{|c|}{ Panel A. Females } & \multicolumn{3}{|c|}{ Panel B. Males } \\
\hline & Parm & $\begin{array}{l}\text { t- } \\
\text { stat }\end{array}$ & & Parm & $\begin{array}{c}\text { t- } \\
\text { stat }\end{array}$ & \\
\hline & - & & $* * *$ & - & - & $* * *$ \\
\hline & 27.827 & 3.27 & & 40.894 & 5.34 & \\
\hline ATHLETE & -0.779 & - & & -0.276 & - & \\
\hline HONORS & 2.590 & $\begin{array}{l}0.63 \\
1.68\end{array}$ & $*$ & 2.357 & $\begin{array}{l}0.24 \\
1.54\end{array}$ & \\
\hline \multicolumn{7}{|l|}{ Concentration } \\
\hline ACCOUNTING & 6.503 & 4.45 & $* * *$ & 4.979 & 3.41 & $* * *$ \\
\hline FINANCE & 9.914 & 4.94 & $* * *$ & 14.171 & 8.59 & $* * *$ \\
\hline MARKETING & 3.228 & 2.41 & $* *$ & -1.001 & - & \\
\hline INTERNATIONAL BUS. & 1.740 & 0.90 & & 0.286 & $\begin{array}{l}0.65 \\
0.14\end{array}$ & \\
\hline CIS & 0.567 & 0.13 & & 1.479 & 0.59 & \\
\hline ENTREPRENEURSHIP & 4.232 & 1.17 & & -0.066 & 0.03 & \\
\hline \multicolumn{7}{|l|}{ Standardized Test Scores /Grades } \\
\hline SAT-M & 0.033 & 3.85 & $* * *$ & 0.032 & 4.41 & $* * *$ \\
\hline SAT-V & 0.028 & 3.29 & $* * *$ & 0.030 & 4.15 & $* * *$ \\
\hline GPA & 4.683 & 2.68 & $* * *$ & 10.826 & 7.36 & $* * *$ \\
\hline FMGRADE & 1.570 & 2.05 & $* *$ & 1.081 & 1.51 & \\
\hline NUMFIN & 2.202 & 5.10 & $* * *$ & 2.153 & 6.22 & $* * *$ \\
\hline TIME & 0.021 & 0.30 & & -0.004 & 0.06 & \\
\hline \multicolumn{7}{|l|}{ ETS Cohorts } \\
\hline 2012 & -1.160 & 0.56 & & -0.543 & 0.25 & \\
\hline 2013 & -4.310 & $\begin{array}{r}0.00 \\
2.11\end{array}$ & $* *$ & -2.415 & $\begin{array}{r}0.25 \\
- \\
1.12\end{array}$ & \\
\hline 2014 & -3.313 & 1.64 & & -1.443 & 0.68 & \\
\hline 2015 & -4.521 & 2.13 & $* *$ & -1.051 & 0.49 & \\
\hline 2016 & -4.207 & 2.03 & $* *$ & 1.281 & 0.60 & \\
\hline Student Perceptions & & & & & & \\
\hline CHALLENGE & 3.499 & 2.54 & $* *$ & 3.630 & 3.19 & $* * *$ \\
\hline $\mathrm{N}$ & 809 & & & 1229 & & \\
\hline R-Square & 0.265 & & & 0.331 & & \\
\hline Adj R-Sq & 0.245 & & & 0.320 & & \\
\hline
\end{tabular}

